\title{
The Right To Social Security Under International Law
}

\section{Seyed Ghasem Zamani*}

Professor of international low-Allameh Tabatabae'i university, Tehran, Iran, Corresponding Author

Ali Azadd Evin

PhD Student of international low-Allameh Tabatabae'i university, Tehran

\section{Doi:10.5901/mjss.2016.v7n5s1p45}

\section{Introduction}

During their turbulent life, humans are always at risk of an unintended and unavoidable events and thus seek to gain pain relief and a way to avoid the consequences of accidents like this. Events such as unemployment, disability, illness, aging, etc. as well as natural disasters can undermine the livelihoods and well-being. In different periods of human life, the fundamental institutions such as family, tribe and relatives were somewhat supportive of their dependents when they were faced by the decisive events or reduction of income and livelihood, but with the industrialization and urbanization process, one of the most important consequences has been breaking the strong bonds of family and extended family, and thus a need to protect people from exposure to these risks and events was formed.

The general definition of Social Security is to repair and compensate all social risks that threaten the lives of individuals and families. In a more general definition, social security is a set of public entities legal actions to protect income following retirement, unemployment, old age, disability, loss of guardian, homelessness, disease and death, and ensuring the well-being of individuals and families by providing public service such as health, housing benefit and so on.

This study examines social security, the definitions and evolution as well as its legalization process, and the results and obligations of government and international obligations arising from this process. Because of the importance and necessity of social security and its association with fundamental rights of human such as the right to life, it is a fundamental right of human rights.

\section{Part One: The Evolution, the Concept and the Scope of Social Security}

This section deals with the statement of principles and in two chapters, tries to study the historical evolution, the meaning and scope of social security.

\section{Chapter One: Social Security from a Historical Perspective}

Use of the term social security has not a long history and became common with the United States 1935 Act $^{1}$ or at the maximum from the early twentieth century. However, after the formation of nation-states in Europe, and as a result of rapid industrial growth and the urbanization crisis on the continent and, perhaps, in other words, following various consequences such as family break, requiring all members of the family to work, poverty and remaining helpless in the face of multiple risks of social life, new measures became required for the protection of individuals against risks such as unemployment, old age, disability and other events, and over time they led to the establishment of social security systems. Social Security's historical evolution is discussed here.

\subsection{Discussion one: Before World War II}

In Europe during the medieval there was was no notion of the right to social security and no there was no public and government responsibility to realize it and the responsibility to protect people against economic insecurity was on the family that at the time mainly took the form of extended family (the social institution consisting of parents and children along with other relatives), the church, and the good nobles who helped the poor. During this period, religious institutions

${ }^{1}$ Maleki, R. (2005). Social security as a human right. Journal of constitutional rights. No. 5. 
(churches) and charities in particular took steps to improve the lives of people². Public officials quite gradually recognized poverty not as moral problem but as a social problem, therefore, some European governments took measures to combat poverty and most striking of them were Poor Laws in 1601 in England, based on which local authorities were obliged to help the poor and keep them in the homes of the poor ${ }^{3}$. In fact, poverty due to unemployment in the UK after 14th century was clear. Another prominent measure was the order of Henry IV (King of England) in 1604, by which some amount shall be deducted from the income of every mine in the UK, and be spent for the purchase of medicine and the treatment of workers in the mines. Legislation related to the poor in countries such as England represented an incomplete and early form of public responsibility to eliminate poverty from those who were unable to obtain help from their families. However, the elimination of poverty often involves accepting personal humiliation, loss of civil rights, compulsory transfer to the homes of the poor, and even some of the couples separated.

Start of Industrial Revolution in the 18th century and the subsequent process of urbanization in the nineteenth century caused many personal problems and instability so that fundamental changes in all aspects of life of Europeans came into existence. By increasing machinary and migration of farmers from the countryside to the cities to find work, working hours increased and wages reduced. These came as all members of the family even children had to work to earn a living. As a result, poverty was dominant in society, while most of the workers were under pressure, scholars like Karl Marx and Friedrich Engels criticized such growing poverty, exploitation and overall economic insecurity for marginalized groups and, children working in the mines, lack of social support for patients, the elderly and the disabled 4 .

Poverty and violent punishment of workers led to nothing but their violent campaign in the UK and other European governments. In 1802 the British Parliament passed a law on working in factories according by which child labor situation improved and their working hours were reduced from 14 hours to 12 hours and hard work were removed from their shoulders.

In 1823 by virture of another law, employment of children younger than 9 years in the textile factory was prohibited. In 1842 the employment of women, girls and boys under ten years of age in underground mines was banned and in 1847 the women's working hours were reduced to 10 hours a day. In other Western countries, laws and regulations were enacted in favor of workers. Following this process, social security system was organized. Workers tried to help each other against the dangers of industrial society and established institutions called friendly societies, societies that were financed by the voluntary participation of the workers in the form of shares. Move into paid work and guarantees of employment contract gradually created a support system that is still the basis of most people's financial security. Therefore, even in advanced countries, up to the nineteenth century, in the face of financial risk, there was no protection but what charity organizations or the accumulation of small funds or labor groups in the small industries, provided. However, in the late nineteenth century, German Chancellor Bismarck considered involvement in the promotion of the welfare of the poor and the needy as the duty of the state.

Thus, Germany became the first government to adopt a system of compulsory social insurance law and benefits applicable to the industrial workforce as a right 5 . Subsequently, other European countries such as France and Belgium, beginning in the late nineteenth century, followed similar patterns. And similar schemes in Latin America (Argentina, Brazil, Chile and Uruguay) were created. As the insurance models became widespread, new risks such as unemployment, including projects were supported, with a range of individuals and groups covered by the extension. Little by little social security schemes financed by taxes were added to compulsory insurance and in the early twentieth century in northern European countries, not only the workers but all the inhabitants were supported by the government. Meanwhile, the economic crisis and the Great Depression between 1929 and 1933 and the government policies for the crisis management led to further progress of most of the new social security plans, particularly in Europe and Latin America and in the United States, there was no social security until $1935^{6}$ and as was said, the term "Social Security" was made popular in 1934 upon approval the US Social Security Act by then president of the US, Roosevelt.

2 See R. Castel, Les métamorphoses de la question sociale: une chronique du salariat, Paris, Paris, 1st ed. Fayard, 1995; Gallimard (Folio Essais), 1999; S. Deakin \& F. Wikinson, The Law of Labour Market: Industrialization, Employment and Legal Conditions (Oxford U. Press 2005).

3 Emmanuel Reynaud, The Right to Social Security - Current Challenges in International Perspective, in Eibe Riedel, Social Security as a Human Right Drafting a General Comment on Article 9 ICESCR - Some Challenges, Springer Publications, 2007, P.19.

4 The social insurance law is a significant issue and as seen from some of the remarks delivered by Bismarck in the German parliament the establishment of a social security system (though incomplete) was mainly aimed to deal with the strengthening of socialist ideas and quelling public unrest resulting from raised public awareness in protest against the abuses of workers, employers and public authorities regarding their welfare. For further reading, see Emmanuel Reynaud, op., Cit, P.P.19-20.

${ }^{5}$ Jean-Michel Servais, op., cit, p.2.

${ }^{6} \mathrm{lbid}$. 


\subsection{Discussion two: World War II and the new era of social security}

The key point in the previous discussion related to the evolution in social security. While the fight against poverty and the protection of people in need was an ethical issue before the nineteenth century, with the incorporation of social insurance and other forms of support in the laws of government, a binding and legal attribute was given to social security, which was a step towards improving social security as a human right. However, in the said period, social insurance and other benefits did not cover all the strata.

New era in which social security tended to be amplified to cover all segments of society relates to Second World War and subsequent periods ${ }^{7}$. In fact, this point is considered as a turning point in the system of international law. During World War II and thereafter, social security underwent many advanced and such important progress occured in all three national, regional and international levels and led to recognition of social security as a human right. World War II and the ensuing crisis led a number of countries to government social security. One major reason for this that also happened during the 1929-1933 economic crisis is that during World War II (1939-1945) private companies were not able to pay the required benefits.

One of the most important developments in social security during the Second World War started from 1945with the famous British economist Beveridge report of $1942^{8}$. By the imposing responsibility on the entire society of people towards those defending the community against the assaults, this report had a significant effect on further advancement of social security. The aim was to extend social security insurance that supported workers to all people, and after the Bismarck system, Britain established a new social security system based on the ideas of Beveridge in 1948, in which all people, regardless of occupation or profession, based on their needs and not their income, were covered by an organization. At the beginning of the Second World War, unlike the First World War, the issue of improving the lives of individuals, social security, meeting the the material requirements and the fight against hunger were among the key issues on which attention was focused. During World War II, an international movement began that highly contributed to the advancement of beliefs and practices related to social security. On August 12, 1941 at the request of the United Kingdom, it was included in the fifth principle of the Atlantic Charter that governments are determined to establish and maintain through collaboration, better conditions of work, a situation favorable to economic progress and better ground for the social security of all nations ${ }^{9}$.

This was a credible Charter in which the United Nations declared their interest in full cooperation between governments in the realm of economy to stabilize and improve working conditions, social and economic arrangements and in parallel the ILO Conference in Philadelphia suggested that the development of security system social was required in order to earn a minimum income for all those who need the enormous amount of support ${ }^{10}$. The contents reflected in the Declaration of Philadelphia contributed to the development of social security. Subsequently, the International Conference of Social Security in Santiago de Chile, that ensuring the means of social security is one of the main drivers of social security was approved. Yet, the biggest change in the social security was its inclusion as a human right in the Universal Declaration of Human Rights ${ }^{11}$, which was approved by the United Nations General Assembly on 10 December 1948 and recognized the social security as a universal right right and since then, shift from social security as a primarily moral and political right to a legal and binding and universal right started. Since then, to ensure the stability of the international aspects of social security, the UN, the ILO and the International Social Security Association (ISSA) have taken a series of measures required to monitor its implementation. Also in the regional human rights instruments such as the European Convention on the human rights, proper sanctions are provided for ensuring government's commitment to the realization of the right to adequate social security. However, the most important point about that the legal process of social security is that today, most states have recognized the right to social security and some of them have even assumed additional obligations in this regard through membership in organizations such as the ILO.

\section{Chapter Two: Concept and Scope of Social Security}

As discussed, in classical international law (before the founding of the United Nations) there was not an integrated social

\footnotetext{
${ }^{7}$ Malekian, R., Ibid, p. 154.

${ }^{8}$ Sir William Beveridge: Social insurance and allied services, presented to Parliament by command of His Majesty, Nov. 1942 (H.M. Stationery Off., U.K., 1969).

${ }_{9}^{9}$ Atlantic Charter, 1941, Principle 5.

${ }^{10}$ Declaration concerning the aims and purposes of the International Labour Organisation (DECLARATION OF PHILADELPHIA), 1946, section III.

11 Universal Declaration of Human Rights, 1948, Article 9.
} 
security and only some instances of it such as social insurance were in place. In this chapter, the conceptual framework, and the scope of social security coverage will be discussed.

\subsection{Discussion one: the conceptual framework of social security}

Social Security has ambiguity as a feature of its definition so that most countries lack the legal description of social security. Since term "social security" came to common use in 1935 and were included in international, regional and national laws, it has had a flexible meaning ${ }^{12}$ and its definition and scope vary among countries and international organizations. The ILO said, referring this matter, "there is no internationally accepted definition of social security yet"13 and that "its meaning is different from country to country obviously ${ }^{14}$." The term is often synonymous with terms such as social welfare, social insurance, and social services. Social security is in the general sense the government efforts to cover damage in some social events according to their facilities and in proportion with the economic and social conditions of the society ${ }^{15}$. Social security arrangements is defined so that it includes private and public (government) or a combination of the two measures that aim to provide income security for individuals and families who are victims of events such as unemployment, old age, illness, work-related injuries, disability and death ${ }^{16}$.

More generally, the Social Security aims to help meet the basic human needs of safety and comfort, and cover natural losses, fear of hunger, disease, old age, unemployment, death and survivors, disability, old age, death and increased costs of treatment and care of the family members. ${ }^{17 "}$

In some instances, social protection and social security are used interchangeably, but, according to one theory, social security is different from social protection and is a wider concept ${ }^{18}$.

This view is also reflected in the report of the International Labour Organization ${ }^{19}$. In the strict sense, social security can be used to refer to measures related to the protection of the poorest, most vulnerable and most disadvantaged people in society ${ }^{20}$. And in a broad sense, social security can include social insurance and social assistance and social services. Social security is created by governments or private companies to maintain income of people and may be in the form of pension insurance, disability insurance, health insurance and unemployment insurance and survivor's insurance. Social insurance schemes are mandatory or voluntary with a group nature and are characterized by sharing resources and risks with a redistributive element. On the other hand, social assistance includes benefits in kind or in cash, which is procured usually based on the ability of governments and out of the overall tax revenue. Provision of food and service at events such as stopping of the flow of work, retirement, disability, unemployment, as well as some international fundraising projects to support children and families are the examples. It seems that, viewed from any angle, social security is a flexible concept and includes social protection, social insurance, and social assistance ${ }^{21}$.

\subsection{Discussion two: The scope of social security coverage}

With regard to the general and relative definitions of social security, determining scope of social security coverage is an open question. In this regard Convention No. 102 of the ILO (1952) is a pioneer in determining the minimum standards for social security. The Convention establishes a framework of minimum standards that provides for nine elements or branches: medical care, sickness benefits, unemployment benefits, old age benefits, work injury benefits, family benefits, benefit, maternity benefits, disability benefits and survivor's benefits' ${ }^{22}$. Convention No. 102 has been designed on the basis that the right to social security, there is no proper pattern for social security but that such pattern is first created and

\footnotetext{
12 Olivier M.P, Smit.N, \& Kalula E.R(eds), Introduction to Social Security, Butterworths Publications, 2004, P. 13.

${ }^{13}$ Systems of social security, newzealand 1949 .P.3

14 The cost of social security 1949-1957 (1961 .P.2.

15 Malekian, R., Ibid, 146.

${ }^{16}$ Taleb, M. (2002). Social security Astan Quds Razavi, Vol. 6, p. 40.

17 ILO, World Labour Report 2000: Income Security and Social Protection in a Changing World, ILO (2000). available at http://books. google.co.za/books?

${ }_{18}$ The ILO Convention concerning Minimum Standards of Social Security,1952(No. 102), available at http://www.ilo.org

${ }^{19}$ Olivier, N.P et al, Ibid.

${ }^{20}$ Charles Fombad, an Overview of the Constitutional Framework of the Right to Social Security with Special Reference to SOUTH AFRICA, 2011, P.2. Available at: repository.up.ac.za/bitstream/handle/.../Fombad_Overview(2013).pdf?

21 ILO, World Labour Report 2000: Income Security and Social Protection in a Changing World, ILO (2000). available at http://books. google.co.za/books?

22 Ibid.
} 
then evolve over time, and so the Convention shall not impose specific obligations for states which ratify it, but provides a series of the objectives of minimum based on the principles mainly agreed that provides a socially acceptable minimum for most governments.

Based on convention No. 102 that envisages the gradual realization of the right to social security, in the event that Member States fail to agree with all of the nine cases or may not afford them, old age benefits, work injury benefits and survivor's benefits shall be provided by the government under every circumstances.

In interpretative comment no. 19 of the Committee on Economic, Social and Cultural Rights of the United Nations that interprets the provisions of the International Covenant on Economic, Social and Cultural Rights act states that the right to social security as provided for in the International Covenant on Economic, Social and Cultural Rights includes the right of access to provided the benefits (in cash or in kind) and its continuation, in case of lack of income due to illness, disability, pregnancy, work injury, unemployment, old age and death of a family member, or the lack of access to health care or insufficient support for families, especially children ${ }^{23}$.

Today, Social Security covers a variety of allowances and pensions. Old-Age Benefits, Disability Benefits, Sickness and Maternity Benefits, Medical Care for Dependents, Work Injury Benefits, Unemployment Benefits, Family Allowance, and Medical Benefits are examples of social security in different countries, especially developed ones. State funds to guarantee different aspects of social security are different. But these resources can generally be classified into 5 categories: Employment-Related System, Universal System, Means-Tested System, Provident Funds System, and Employer-Labiality System.

\section{Part Two: The Place of Social Security in International Law}

With the end of the Second World War that had killed more than 50 million, the international community discerned the necessity of avoiding another devastating war and establishing sustainable peace and consolidation in the world merely through the realization of human rights and solving the economic and social problems of the human society. With the approval of the UN Charter and the establishment of the United Nations, and the subsequent adoption of the Universal Declaration of Human Rights, the international community showed its determination to move towards sustainable peace and security. Nevertheless, given the importance of social security and its scope, it played a major role in establishing peace and security as one of the objectives of the UN Charter ${ }^{24}$. This part tries to investigate the legal status of Social Security under international law in two chapters.

\section{Chapter One: Social Security as a Human Right}

This chapter discusses the most important international and regional documents that cover the right to social security as a human right. Also, provision of the social security provisions in the constitutions and statutes of states, and the influence of international instruments on adoption will be examined.

\subsection{Discussion one: international and regional documents}

Many international and regional documents and charters have recognized the right to social security; some of them are as follows:

- Universal Declaration of Human Rights (1948): According to Article 22 of the Universal Declaration of Human Rights: "Everyone has the right to social security as member of society, and can benefit with the assisce of national and international efforts given the organization and resources of each country the economic, social and cultural rights in consistence with the dignity and the free development of human personality". In the twenty-third article, it reads as follows: "a) Everyone has the right to work and the right to free choice of employment with fair and satisfying conditions, and has the right to protection against unemployment. b) Everyone has the right to be paid equal wage for the same work, without advantage. C) Everyone has the right to receive a fair wage and satisfying for him for work such that it would provide him and his family a means of livelihood, which is worthy of the dignity of human perfection and, if appropriate, the right to use all means of social protection".

Article Twenty-fifth completes the previous articles and stipulates that: "a) Everyone has the right to have a

${ }^{23}$ Charles Fombad, op., cit, P.3.

${ }^{24}$ International Labour Organization (ILO) Convention 102 on Social security, December 2011, Text available at: www.ilo.org 
standard of living ensuring health and well-being of himself and his family, including food, clothing, housing and medical care. The right to essential social services at unemployment and illness and the inability and widowhood and old age or in other cases in which circumstances disrupted means of subsistence out of his will".

- International Covenant on Economic, Social and Cultural Rights (1966): This binding covenant formally recognizes right to social security as a human right that belongs tothe category of economic, social rights, but also supports the families and recognizes the right of everyone to have a good standard of living, including food, clothing and housing, and progress of living conditions ${ }^{25}$. According to the Covenant, member states recognize that every person has the right to social security, including social insurance. Convention also contains provisions on the protection of mothers on maternity leave ${ }^{26}$ and social security benefits during pregnancy, the public enjoyment of the provision of medical assistance in case of illness ${ }^{27}$, and the right to work and labor conditions ${ }^{28}$, all of which are related to social security.

- Documents of ILO (1919): This organization before and after the founding of the United Nations and the ratification of international human rights instruments had a very important role in the promotion and realization of the right to social security around the world. After the Second World War, the organization adopted dozens of protocols and twenty recommendations indicating approval of social security and the most important of which is the protocol number 102 that provides the minimum basis of social security and the Protocol that was approved in 1952 that provides the international minimum standard for the level of social security, based on the principle that social security shall cover all events and extend to all people gradually ${ }^{29}$. Almost all European countries, and most countries in Latin America and the Caribbean follow the pattern set out in Convention No. 102. ILO Recommendation No. 202 (2012) also affirm that the right to social security is a human right and is an economic and social necessity for development and progress ${ }^{30}$.

In addition to the items mentioned above, several international and regional treaties recognized the right to social security as a human right; the most important of these include the following: International Convention on elimination of all forms of Racial Discrimination (Article 5), the Convention on the elimination of all Forms of Discrimination against Women (Article 11), the Convention on the Rights of the Child (Article 6), Europe Social Charter (Articles 12-14), the European Charter of Fundamental Rights (Article 34), the American Declaration of human rights and duties (Article 16), the African Charter on Rights Human and Peoples Convention for the Protection of Persons with Disabilities (Articles 25 and 28), and the International Convention on the Protection of the Rights of All Migrant Workers and their families (Articles 27 and 54).

\subsection{Discussion two: National regulations}

The right to social security today is a universal right that is embodied in the constitutions and statutes of most countries. Mainly inclusion of social rights (including social security) in the constitutions occured after the First World War and upon the founding of the ILO, it spread across Europe. The first time, social rights were included in the constitutions of the Weimar Republic (1919) and Finland (1919) and subsequently other countries such as Estonia (1920), Poland (1921), Italy (1927), Greece (1927), Portugal (1933), Spain (1933), and Ireland (1937). In the US, the motivating force for the development of social security came from crises of the 1930s that led to the enactment of the Social Security Act in 1935. The said law provided for the plans to cope with risks such as old age, survivors, disability and unemployment. The governments of Brazil, Uruguay, Argentina, Cuba, and Chile implemented their first insurance plans in the 1920s and 1930s. Mexico, Costa Rica, Ecuador, Panama, Colombia, and Peru also executed insurance plans first in 1940s, while Nicaragua, Bolivia, Venezuela, Guatemala, El Salvador and Honduras did so in 1950s and 1970s.

After World War II and the establishment of the United Nations, governments recognized social security as a human right, and began to realize that it occurred in form of both legislation and the adoption. For example, more than 150 states ratified the International Covenant on Economic, Social and Cultural Rights and the Convention on the Rights of the Child was ratified by 192 countries; both documents stipulated regulations on social security. Another example is

25 "International Covenant on Economic, Social and Cultural Rights". Office of the United Nations High Commissioner for Human Rights. 1966.

${ }^{26}$ United Nations Charter, 1045, Article (1)1.

${ }^{27}$ Article 11 of the International Covenant on Economic, Social and Cultural Rights (ICESCR) (1966).

28 Ibid, Article 3.

${ }^{29}$ Ibid, Article (2) 10.

$30 \mathrm{lbid}$, Article 12. 
the ILO Convention No. 102 based on which more than 30 African countries have designed insurance programs ${ }^{31}$.

Today, almost all European states have adopted the right to social security in their constitutions. This human right is included in the preamble of the Constitution of France, Article 23 of the Constitution of Belgium, Article 75 of the Constitution of Greece, Article 30 of the Constitution of the Czech Republic, Article 75 of the Constitution of Denmark, Article 28 of the Constitution of Estonia, Articles 41, 47 and 50 of the Constitution of Spain, Article 3 of Constitution of Ireland, Articles 31, 32 and 38 of Italian constitution, Article 9 of the Constitution of Cyprus, Article 20 of the Constitution of the Netherlands, and the constitutions of other countries such as Latvia, Lithuania, Luxemburg, Hungary, Malta, Poland, Portugal, Slovenia, Slovakia and Finland. While lower levels of social security exist in Africa, this right is included in the constitutions of most countries, including South Africa, Kenya, Ethiopia, Nigeria, and Uganda.

Meanwhile, governments have chosen various methods for the realization of the right to social security. For example, the South Korean government has adopted a gradual approach, in which in a 12-year period, health insurance coverage was extended to the entire population ${ }^{32}$. The same procedure adopted by the Tunisian government and health and pension coverage for 60 per cent of the working population in 1989 was increased to 84 percent in 1999. Karstaryka similarly made gradual expansion of health coverage and the Brazilian government chose to increase in three decades the support for older people. In summary it can be said that today almost all states, through legislation or ratification of international and regional instruments, seek to realize the right to social security for their residents.

\section{Chapter Two: Implementation of the Right to Social Security}

After the introduction to the concept and scope and legal status of social security in international human rights documents the national and national laws of states, the issue now is how the states fulfil their international obligations in relation to the realization of this right and we went on to study the characteristics and advantages of such right that can help to facilitate the realization of it.

\subsection{Discussion one: The obligations and responsibilities of States}

In international law, states are required by their acceptance of the obligations relating to the provision of conventions provide social security. States that have assumed regional and international obligations with regard to the realization of the right to social security are responsible for providing it. In addition, inclusion of social security rights in constitutions and ordinary laws make them them committed. However, in a classification of different categories of human rights, the right to social security is among the rights of the second generation of human rights (economic rights, social and cultural). Considering the fact that the realization of the second generation of human rights requires positive action by governments and financial resources, fulfilment of obligations concerning that such right should be consistent with the resources, facilities and capabilities of governments committed. On the other hand, most of the second generation of human rights cannot be realized without the participation of individuals and communities, institutions and private companies and government action. This is true of Social Security as well, but it does not mean that the responsibility of states for the realization of the right to social security will be divided between the society and individuals. Governments themselves should organize or run social security plans ${ }^{33}$.

Accordingly, despite duty of the whole society for social security, implementation and monitoring duty of state cannot be reduced and major execution and overseeing of this right may not be assigned to private sector, because this right is a fundamental human right and is closely related with other such fundamental rights including the right to food and housing, the right to work and the right to have the support of family relationship and interdependence, and only governments can be considered responsible ${ }^{34}$.

As for the government's commitment to second generation of human rights, International Covenant on Economic, Social and Cultural Rights provides that "each country party to the Covenant undertakes to attempt through international cooperation, especially in economic projects and technical projects, using most of their available resources to ensure the full implementation of the rights recognized in this Covenant gradually with all appropriate means, especially with the

\footnotetext{
31 Ibid, Articles 6-7.

32 In the discussion of the scope of social security, a report on the provisions of Convention No. 102. is given.

33 Jean-Michel Servais, op., cit, p.7.

${ }^{34}$ African Charter on Human and Peoples Rights (1981) has not particularly recognized the right to social security, but it has some of the examples. According to Article 16 of the Charter: 1. Everyone has the right to physical and mental health. 2. States Parties shall take measures necessary to protect the health of ther people and ensure that people in their countries receive receive medical care we needed.
} 
legislative act"35. It is seen that noted that gradual nature of fulfilment of economic, social and cultural commitments of states is provided for by conventions and the discretion for manner of fulfilment of second generation rights has been granted to them.

Given the importance and scope of the right to social security and its relationship with other fundamental human rights, and to explain this right, commission of the economic and social rights of the United Nations issued an interpretive comment and distinguished three social security commitment of states which are briefly provided below:

1. Commitment to comply: This obligation requires States Parties to the present Covenant to refrain from interfering directly or indirectly in the enjoyment of the right to social security. Commitment includes rafraining from engagement in any practice or activity that avoids or limits access to social security desirable. Commitment further includes refraining from arbitrary interference in the customary or traditional self-employed arrangements of social security systems, and fimrs created by natural or legal persons for realizing social security ${ }^{36}$. The first obligation of government is avoidance of negative interference in private social security and respect for the integrity of of social security.

2. Commitment to support: ${ }^{37}$ this commitment requires member states to prevent any interference of third parties in the right to social security. Third parties include individuals, groups, corporations and other entities. Commitment included the adoption of necessary measures and effective legislative and other measures to prevent the exclusion of third parties equal access to social security schemes ${ }^{38}$. Also commitment requires that where social security schemes are performed or overseen by third parties, the Member States shall be responsible for the implementation of the national social security system and to guarantee and ensure that private agents provide social security in equal, favorable, and risk free manner. To prevent such abuse, there should be an effective regulatory system, including independent monitoring, real public participation and penalties for cases of default 39 . Therefore, not only must there be respect for private social security, but the real function needs to be supported and in fact, apart from the legislative role, a more active role is assigned to the government.

3. Obligation to fulfil: This obligation requires that member states shall take necessary measures including implementation of social security schemes. Obligation to fulfil may be divided to obligation to facilitate, to provide encouragement and to supply ${ }^{40}$. In addition, member states are obliged to provide social assistance or other assistance to support groups and individuals with disabilities who are unable to support themselves through contribution to the types of insurance and other contributive projects ${ }^{41}$.

\subsection{Discussion two: The features and advantages of the right to social security}

The right to social security as a human rights shares features of other rights and further has specific advantages and characteristics. This topic briefly discusses the features and benefits of this right. As the first character, it is quite widespread and universal (universality). According to Articles 22 and 35 of the Universal Declaration of Human Rights and Article 9 of the International Covenant on Economic, Social and Cultural Rights, Social Security belongs to everyone. It means the necessity of supporting (by governments) of all residents (territory) and the expansion of social risk insurance for all the members of the community ${ }^{42}$. Universalism also means that Social Security is not limited to formal employment and informal employment also is covered by it. Such nature leads to the protection of women, children, migrants and asylum seekers, deprived minorities and the permanent disabled. The second advantage of the right to social security is its comprehensiveness.

Social security system covers all social risks (including nine branches set out in ILO Convention No. 102 as a minimum standard and on the other hand, covers benefits and protections provided shall be such as to provide decent life

\footnotetext{
$35 \mathrm{Ibid}$

${ }^{36}$ Soonman Kwon, Achieving health insurance for all: Lessons from the Republic of Korea (ESS Paper No. 1, 2002).

${ }^{37}$ See: Mohamed Chaabane, Towards the universalization of social security: The experience of Tunisia (ESS Paper No. 4, 2002).

${ }^{38}$ George Katrougalo, Indivisibility of rights: The case of the right to social security, P. 15. Available at: www.juridicas.unam.mx/wccl/ ponencias/10/184.pd

${ }^{39} \mathrm{lbid}$

40 ICESCR, Article (1)2.

${ }^{41}$ CESCR, General Comment no. 19, para38 .

${ }^{42}$ Badini, H. (2008). Critical study of the legal system of social security of Iran. Journal of Law of Faculty of law and political science of University of Tehran, 38(4).
} 
for people, in fact, supports of social security should not only be comprehensive but also have the necessary depth ${ }^{43}$.

One of its characteristics is the principle of equality, equal treatment and non-discrimination. Based on this principle, all citizens have equal social security no matter of what ethnicity, race, language, gender and even nationality. Much attention has been paid to the negative aspects of the right to non-discrimination in terms of gender and race, but the general deprivation or non-equal treatment other groups, such as migrants and asylum seekers can raise important issues. Non-discrimination has been provided for in documents such as the International Covenant on Economic, Social and Cultural Rights ${ }^{44}$, and the Convention on the Elimination of All Forms of Racial Discrimination. Another advantage of this right, like other human rights, is that it is included in internationally binding instruments. As was already mentioned, more than 150 states have ratified International Covenant on Economic, Social and Cultural Rights and 192 states have ratified the CRC and both documents stipulated regulations on social security and Convention No. 102 of international organizations ratified by nearly 50 governments has laid down the standards of the said right.

Despite the important issues that were discussed, perhaps the most important advantage of the right to social security is existence of international institutions supervising its implementation and exploring and developing it. International Labour Organization, since the establishment, has always supported the establishment of social security systems and the realization of its objectives, in particular during the Second World War. Moreover, to ensure sustainability of the international aspects of social security, the UN, the ILO and the International Social Security Association have adopted measures in this regard and were required to monitor its implementation. International Union of Social Security is the most important international institutions that has brought together organizations, management departments and institutions of the social security and has always worked closely with the ILO in the development of social security. Committee on Economic, Social and Cultural has had the leading role in defining and interpreting the provisions of the Covenant on Economic, especially the right to social security, as mention was made in previous discussions of an interpretive comment of this committee.

\section{Conclusion}

Despite efforts to improve the situation of social security at the international level, currently about 75 to 80 percent of the world's population are living in a state of lack of social security and given the difficulties faced by governments in recent years, security coverage social in some countries has been declining. This fact shows that international cooperation in view of paragraph 2 of Article 55 of the UN Charter to promote the right to social security (as a social right) has not been achieved as desired. On the other hand, the practical realization of human rights is a at the beginning of the way and governments, organizations and non-governmental and international companies still do not pay enough attention to proper realization of human rights. However, the second generation of human rights including social security and welfare rights can be expected to realized only proportional to resources, facilities and capabilities of the government and some social and cultural realities. It should be noted that the commitment to the progressive realization cannot and should not be an excuse for neglect or abuse of the right. Second generation rights, despite the difference in the quality and process of realization, are not different in terms of the government's commitment to the implementation of effort and good faith in the execution, with civil and political rights (first generation) and this marks the indivisible nature of human rights.

\section{References}

Fatemi, M. (2009). Human rights in the contemporary world: analytical exploration of rights and freedom. Tehran: Shahre Danesh, Institute of legal studies and research. Vol. 2.

Badini, H. (2008). Critical study of the legal system of social security of Iran. Journal of Law of Faculty of law and political science of University of Tehran, 38(4).

Maleki, R. (2005). Social security as a human right. Journal of constitutional rights. No. 5.

Riedel, Eibe, Social Security as a Human Right; Drafting a General Comment on Article 9 ICESCR - Some Challenges, Springer Publications, 2007.

M.P, Olivier, N. Smit, \& E.R, Kalula, Introduction to Social Security, Butterworths Publications,2004.

Servais, Jean-Michel, International Standards on Social Security Lessons from the past for a better implementation, 2014, available at: http://islssl.org/wp-content/uploads/2014/12/Servais_2014_Asian_Conf.pdf.

Katrougalo, George, Indivisibility of rights: The case of the right to social security, available at: www.juridicas.unam.mx/wccl/ponencias/ 10/184.pd

${ }^{43} \mathrm{Ibid}, 62-63$.

${ }^{44}$ ICESCR, Article (2)2. 
Fombad, Charles, an Overview of the Constitutional Framework of the Right to Social Security with Special Reference to SOUTH AFRICA, 2011, available at: repository.up.ac.za/bitstream/handle/.../Fombad_Overview(2013).pdf?

Kwon, Soonman, Achieving health insurance for all: Lessons from the Republic of Korea (ESS Paper No. 1, 2002).

Chaabane, Mohamed, Towards the universalization of social security: The experience of Tunisia (ESS Paper No. 4, 2002).

United Nations Charter (1948).

The International Covenant on Economic, Social and Cultural Rights (ICESCR) (1966).

Universal Declaration of Human Rights (1948)

UN Committee on Economic, Social and Cultural Rights (CESCR), General Comment No. 19: The right to social security, (2008), E/C.12/GC/19

International Labour Organization (ILO) Convention 102 on Social security (2011).

Declaration concerning the aims and purposes of the International Labour Organisation (DECLARATION OF PHILADELPHIA) (1946). the UN Committee on the Elimination of Discrimination against Women (CEDAW)

The Atlantic Charter (1941), available at: http://americanhistory.about.com/od/worldwarii/a/atlantic_charte.htm

Sir William Beveridge: Social insurance and allied services, presented to Parliament by command of His Majesty, Nov. 1942 (H.M. Stationery Off., U.K., 1969).

www.ilo.org

www. un.org 